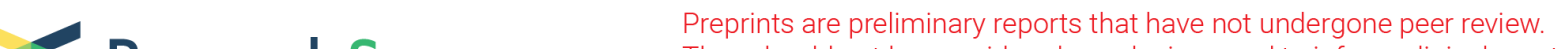 $\begin{array}{ll}\text { Research Square } & \text { They should not be considered conclusive, used to inform clinical practice, } \\ \text { or referenced by the media as validated information. }\end{array}$
}

\section{Are lumbar traction strength and sit and reach flexibility associated with the development of musculoskeletal pain in two years in university staff?}

Vinicius Muller Reis Weber ( $\nabla$ viniciusweber1994@gmail.com )

Universidade Estadual de Londrina https://orcid.org/0000-0003-3303-9326

Daniel Zanardini Fernandes

Universidade Estadual de Londrina Centro de Educacao Fisica e Esporte

Bruno Sergio Portela

Universidade Estadual do Centro-Oeste

Marcelo Romanzini

Universidade Estadual de Londrina Centro de Educacao Fisica e Esporte

Leonardo Alex Volpato

Universidade Estadual de Londrina Centro de Educacao Fisica e Esporte

Stefanie Milla

Universidade Estadual do Centro-Oeste

Wagner Menna Pereira

Universidade Estadual do Centro-Oeste

Edgar Ramos Vieira

Florida International University Nicole Wertheim College of Nursing and Health Sciences

Enio Ricardo Vaz Ronque

Universidade Estadual de Londrina Centro de Educacao Fisica e Esporte

Marcos Roberto Queiroga

Universidade Estadual do Centro-Oeste

Research article

Keywords: Musculoskeletal disorders, muscle strength, workers

Posted Date: April 21st, 2020

DOI: https://doi.org/10.21203/rs.3.rs-22509/v1

License: (c) (1) This work is licensed under a Creative Commons Attribution 4.0 International License.

Read Full License 
Page 2/15 


\section{Abstract}

Background: Increase of musculoskeletal disorders is related to an economic burden; also elevate time spend in sedentary behavior can lead to a decrease in physical fitness and consequently an incidence in musculoskeletal disorders. The aim of the study was to evaluate if low lumbar traction strength and flexibility could predict musculoskeletal pain in university staff in two years.

Methods: This is a longitudinal study with 2-year follow-up. Fifty-three university staff members participated in this longitudinal study: age $=38 \pm 8$ years, height $=171 \pm 10 \mathrm{~cm}$, body mass $=75 \pm 14 \mathrm{~kg}$, and body mass index $=26 \pm 4 \mathrm{~m} / \mathrm{kg}^{2}$. The participants performed the lumbar traction and the sit and reach tests, and completed the Corlett and Bishop body map and musculoskeletal pain questionnaire at baseline and two years later.

Results: There was a $4 \%$ increase in pain prevalence on year 2 , but $62 \%$ of the participants remained in the same pain classification. Men presented $11 \%$ decrease in lumbar traction strength, whereas women presented $21 \%$ decrease in strength. Flexibility level at baseline was not associated with developing pain. However, individuals in the lower $75^{\text {th }}$ lumbar traction strength percentile at baseline had 3.2 higher odds of reporting musculoskeletal pain two years later than those in the higher $25^{\text {th }}$ strength percentile.

Conclusion: University staff presented decreases in lumbar traction strength and flexibility over a two year period. Weaker individuals at baseline were more likely to report musculoskeletal pain two years later than those who were stronger. Flexibility levels were not associated with developing pain.

\section{Introduction}

New technologies and the improvement of work practices have benefits, but also create health risks for workers [1]. New technologies can affects workers' exposures through gestures, postures and mental activities required to sustain high productivity. Office workers spend up to two-thirds of their working hours in sedentary postures [2]. This has negative effects on their health because they spend most of their wake time at work $[3,4]$. Musculoskeletal disorders (MSDs) present various symptom episodes and can happen in workers for many causes like excessive repetitions, high biomechanical and psychosocial demands, heavy lifting and social habits [4, 5]. MSDs manifest as pain and malfunction of the body structures and tissues; they are sometimes called repetitive strain injuries, and have a significant effect on the economy $[6,7]$. MSDs are one of the main causes of work absence. For example, office workers spend on average 130 days away from work due to MSDs; this affects workers' health and represent an economic problem [8].

The increased incidence of MSDs is related to the changes in peoples' daily habits, decreases in physical activity levels [9, 10], low physical fitness [11-13], sedentary behavior [14], and low flexibility [15]. Individuals with predominantly sedentary work can reach up to 12 hours in sedentary behaviours (e.g. computer work and watching TV); these individuals tend to present low strength and be overweight [16]. Workers that increased their flexibility levels (measured by their seat and reach distance) reduced their 
musculoeskeletal pain [17]. Heneweer et al. [12] found a significant association between physical fitness and back pain in workers; the workers in the $>50$ percentile had less back pain then those in the $<25$ percentile. Workers in predominantly sedentary professions can lose strength over time due to low physical activity levels because physical inactivity can decrease motor unities, innevertion and apoptosis of type 2 muscle fibers. These morphological changes are called disuse syndrome [18].

University staff perform many functions and absences can interfer in the provision of services, affecting the populations that depend on those services. Studies that describe factors associated with MSDs in other workers are available in literature [5], but very few studies have evaluated the risks for MSDs among university staff this is one of the first longitudinal studies that assess the association between pain, strength and flexibility in university staff members.

\section{Material And Methods}

\section{Sample}

This two-year long longitudinal study was approved by the Local Ethics Committee ( ${ }^{\circ}$. 49548/2012 and $857.658 / 2014)$. All university staff members were invited to participate. Those who agreed, signed an informed consent form. The inclusion criteria was working full time exclusively as an university staff member. The exclusion criteria was any injury, recent surgery, and/or inability to complete the tests. The baseline assessment included 131 subjects (72 men and 59 women); 53 of these (32 men and 21 women) had validated data in baseline and follow-up. Individuals were not included in the analysis if they did not have both measures of flexibility and strength. The workers that were not found at their job posts at follow up, were visited on three separate attempts on alternate times and days.

\section{Data Collection}

The baseline data was collected in 2012 and the follow-up data in 2014. All data was collected during work hours. The participants reported their body weight and height, and completed the Corlett and Bishop body map and musculoskeletal pain questionnaire [19] individually, after an explanation. After that, the participants performed the lumbar traction and the sit-and-reach tests. All tests were conducted by a trained researcher. Self-reported body weight and height measures of adults have good validity and reliability [20-22]. Body mass index (BMI) was calculated based on the self-reported measures.

\section{Evaluation of musculoskeletal pain}

The assessment of musculoskeletal pain prevalence and location was performed using the questionnaire and body map by Corllet and Bishop [19] and included an evaluation pain in 11 different body parts. The questionnaire was presented and explained to the university staff members and they completed the questionnaire individually.

\section{Strength and flexibility measurements}


Strength was assessed using a lumbar traction dynamometer with a capacity of $200 \mathrm{kgf}\left(\right.$ Crown ${ }^{\circledR}$, Filizola, São Paulo, Brazil) following a standardized protocol $[23,24]$. The participants were explained the procedures and completed two familiarization trials before three maximum strength testing trials with two-minute intervals between trials. The highest strength value was used in the analysis.

The lumbar traction test was performed with the trunk bent and arms and legs extended, with the handle positioned at knee height (Figure 1a). The tester held the bar, and at the signal, a maximum extension strength test was performed.

The sit-and-reach test was used to assess hamstring and lumbar flexibility [25]. It was performed using the procedures described by the American College of Sports Medicine on a standard sit-and-reach box [26]. The participants sat barefeet with their feet $15 \mathrm{~cm}$ apart and touching the box. The subjects leaned forward slowly reaching as far as possible while keeping their hands adjacent to eachother (Figure 1b). The participants were explained the procedures and completed a familiarization trial followed by three testing trials. Each measure was recorded to the nearest $\mathrm{cm}$. The highest value was used in the analysis.

\section{Statistical Analysis}

The data was tested for normality using the Shapiro-Wilk test. Parametric values were presented as Mean and Standard Deviation (SD) and non-parametric values were presented as Median and Interquartile Range (IQR). Pain prevalence was presented as percentages. Baseline and follow up values for pain, strength and flexibility were compared using paired T tests. Percentage of strength decline was calculated. Strength and flexibility association with pain by sex was evaluated by comparing those at or above the $75^{\text {th }}$ percentile with those betllow using the Pearson Chi-square test. Odds ratios were calculated adjusting for age and BMI. For the variables whith significant association, a binary logistic regression was conducted in SPSS 25.0 and a 5\% significance level was used for all tests.

\section{Results}

Table 1 shows the sample characteristics at baseline and follow-up. Body mass and BMI increased significantly over time $(P<0.05)$. The average weight gain was $1.7 \mathrm{~kg}$. The prevalence of pain was $58.5 \%$ at baseline and $62.2 \%$ at follow up; $62.3 \%$ of those with pain remained at the same pain level.

\section{Table 1 - Sample characterization in the Baseline and follow-up.}


Baseline

\begin{tabular}{llllllll}
\hline & $\begin{array}{l}\text { Men } \\
(\mathbf{n}=\mathbf{3 2})\end{array}$ & $\begin{array}{l}\text { Woman } \\
(\mathbf{n}=\mathbf{2 1})\end{array}$ & $\begin{array}{l}\text { Total } \\
(\mathbf{n}=53)\end{array}$ & Men & Woman & Total & D Total \\
\hline Age (years) & 36.5 & 39.9 & 37.8 & 39.0 & 41.5 & 40.0 & 2.4 \\
& \pm 7.7 & \pm 8.7 & \pm 8.2 & $\pm 7.9^{*}$ & $\pm 10.4^{*}$ & $\pm 8.9^{*}$ & \\
\hline BM & 81.3 & 64.6 & 75.0 & 83.8 & 67.2 & 78.5 & 1.7 \\
$(\mathbf{k g})$ & \pm 11.2 & \pm 10.4 & \pm 13.6 & $\pm 13.6^{*}$ & \pm 11.5 & $\pm 15.0^{*}$ & \\
\hline Stature $(\mathbf{m})$ & 1.80 & 1.60 & 1.71 & - & - & - & - \\
& \pm 0.1 & \pm 0.1 & \pm 0.1 & & & & \\
\hline BMI $\left(\mathbf{k g} / \mathbf{m}^{2}\right)$ & 26.2 & 24.5 & 25.5 & 27.1 & 25.3 & 26.5 & 0.6 \\
& \pm 3.6 & \pm 4.3 & \pm 3.9 & $\pm 4.8^{*}$ & \pm 5.0 & $\pm 4.9^{*}$ & \\
\end{tabular}

Pain

n (\%)

No (\%)

Yes (\%)

* $\mathrm{P}<0,05$, comparision between Baseline and Follow-up
Follow-up

Tracking

(\%)

62.3

$\begin{array}{lll}17(53.1) & 5(23.8) & 22(41.5) \\ 15(46.9) & 16(76.2) & 31(58.5) \\ & \end{array}$

The prevalence of pain per body part at baseline and follow up is presented in Figure 2. The prevalence of pain increased in the back, neck, shoulders, arms, and hands. Other regions presented only slight variations $(<5 \%)$.

Figure 3 presents the comparison between baseline and follow-up strength and flexibility for men and women. Both flexibility and strength significanty decreased between $8 \%$ and $21 \%$.

Table 2 presents the odds ratios. Low strength at baseline was significantly associated with developing pain in the follow up, but lower flexibility at baseline was not associated with developing pain at follow up. The binary logistic regression, adjusted to age and BMI, showed that the university staff who had strength values below the $75^{\text {th }}$ percentile at baseline had 3.2 times $(P=0.043)$ more chances of presenting pain at follow up.

At follow up, those in the lower $75^{\text {th }}$ extension strength percentile had 5.6 higher odds of reporting musculoskeletal pain than those in the higher $25^{\text {th }}$ strength percentile $(P=0.01)$. 


\section{Variables}

Median [IQR]

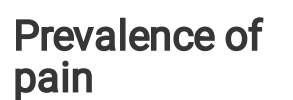

(\%)

Chi

Square

Odds

Ratio $_{\text {adjusted* }}$

$\mathrm{Cl} 95 \% \quad P$

$P$

LTS Baseline

(kgf)

$375 \%(n=13)$

191.5]

$<75 \%(\mathrm{n}=40)$

$90.0[65.0-$

122.0]

38.5

$0.042 \quad 1.00$

0.043

70.0

4.17

1.04 -

16.63

LTS Follow-up

(kgf)

$375 \%(n=13)$

$137.0[72.5-\quad 30.8$

$0.007 \quad 1.00$

0.01

$<75 \%(n=40)$

72.5

6.52

$1.56-$

$78.0[48.0-$

$111.75]$

WB Baseline

(cm)

$375 \%(n=12)$

$<75 \%(\mathrm{n}=41)$

32 [28-36] $\quad 58.3$

0.749

$22[13-26]$

63.4

WB Follow-up

(cm)

$\begin{array}{lll} & 30.0[22.37- & 66.7 \\ & 31.87] & \\ <75 \%(n=41) & 18.5[10.75- & 61.0 \\ & 22.0] & \end{array}$

Note: LTS: Lumbar Traction Strength; WB: Wells Bench; *All values were adjusted for age and BMl; The binary logistic regression was applied only for the values who had significant association by the ChiSquare test; The percentile values were initially classified according to sex and then grouped.

\section{Discussion}

The aim of the study was to evaluate the association between strength, flexibility, and musculoskeletal pain in university staff members over the course of two years. Our main findings show significant loss of strength and flexibility over time. As for pain, there was a variation of approximately $4 \%$, being that $62.2 \%$ of individuals presented some pain in the follow-up, with a higher frequency in the back, neck, shoulders, arms and hands regions. When the strength of individuals was associated to the presence or absence of pain, the results showed that the individuals with less strength at baseline (Percentile<75) presented a 3.2 higher chance of pain 2 years later and for individuals with the worst classification of strength in the follow-up, the chance increased up to 5.6. 
When compared to existing literature, our study shows higher strength loss percentages than other demographic groups (elderly and adults without sedentary professions) (Figure 4). Strength loss over the years is a natural process. People reach peak muscular mass near the age of 25 and from age 45 on, the decline becomes more evident [27]. Some studies showed lower strength loss values than the presented study [28-33]. However, the group of people from previous studies were composed by older adults, which limits comparisons. This can be explained by the sedentary nature of the work of the individuals. Spending many hours in sedentary behavior is inversely associated with muscular strength and percentage of lean mass [34], and is characterized by the disuse syndrome [18, 31]. Another possible factor that explains higher strength loss values than the studies with elderly populations, is that individuals with higher strength values at the baseline, when not perfoming physical exercise, present higher values of strength loss[31].

When the subjects were separated in groups by lumbar traction strength, the weakest presented 3.2 times more of a chance of presenting pain in the future and the value is 5.6 times higher when the analysis is transversal, if compared to the strongest participants. Weber et al. [35] found similar results of the present study, in transversal analysis, in which the lowest quartiles showed an exposure for musculoskeletal pain (OR: $3.47 ; 1.27-9.49$ ). Also, the reported study showed the intensity of pain felt, noting a pattern in the sensitivity as the values are moderate for all spots. The extensor muscles of the lumbar spine are responsible for the stability of the spine and consequently to prevent injury, however the atrophy of these muscles can generate localized chronic pain $[36,37]$. However, there is evidence that physical exercise programs that improve strength in people with musculoskeletal pain in the lumbar region, also result in a lower number of individuals with pain post-intervention [38].

When the pain location was evaluated, the regions that presented a higher increase in pain frequency were the neck, back, shoulder and hand regions. Scarabottolo et al. [39], found higher pain prevalence in the neck region in adolescents physically inactive and concluded that an occupational activity can be a factor of risk for pain. This fact is justified by the fact that sedentary activities and sitting positions increase the static contraction time of the regions that promote body stabilization (neck, shoulder, and back), causing an overload and increased muscle fatigue, resulting in musculoskeletal pain [14, 40]. The study demonstrates the presence of skeletal muscle pain in $62.3 \%$ of participants and an incidence of painful symptomatology of $4 \%$. These results can be justified by the studies mentioned above and the fact that this group of people can last up to 12 hours in sedentary behavior [16].

Although the participants showed a decrease in flexibility values over the years, this study did not find significant associations between flexibility evaluated by sit-and-reach test and musculoskeletal pain, in neither transversal or longitudinal associations. Battie et al. [41], found that flexibility is not associated with lumbar pain in industrial workers, besides, the workers with lumbar pain history presented lower values of flexibility. Although, a possible explanation for the flexibility results without significant, is due to the characteristic of the sit-and-reach test, who didn't assess flexibility in other regions; the test is good to measure hamstring and lumbar flexibility, but can't be generalized [42]. Also, the spots with a higher 
prevalence of pain in follow-up (neck; shoulder; arms; hands; back) have not evaluated by flexibility with the sit-and-reach test.

The strength of this study can be related to the fact that the study has a longitudinal character. The study also increases in the explanation of associated factors of muscular pain, and it presents percentages of muscle strength loss for university workers, a population that development functions in hospitals, administration of public services, research, and security. However, the limitations of the study are due to high sample loss. Besides, the characteristic of the sample was kept, once the individuals that were lost were equal to the ones who followed, this fact was confirmed when compared the values of characterization (body mass; body mass index; strength and flexibility) of the individuals that didn't remain in the research and their pairs. Also, a analysis without stratified for the genders, and the evaluation of flexibility in only one body region, were included as a limitation.

In accordance to the information presented above, it can be concluded that university staff members with a predominantly sedentary profession, present high rates of musculoskeletal pain, mainly in the trunk regions (lumbar, back, shoulders and neck). Thus, these workers have high rates of strength loss and flexibility. In addition, muscle strength can predict painful symptomology even after 2 years.

\section{Declarations}

\section{Ethics approval and consent to participate}

This study was approved by the Ethics Committee of Midwestern Paraná State University. Written, informed consent was obtained from each participant.

\section{Consent for publication}

Not applicable

\section{Availability of data and materials}

The datasets used and/or analysed during the current study are available from the corresponding author on reasonable request

\section{Competing interests}

The authors declare that they have no competing interests.

\section{Funding}

Not applicable

\section{Authors' contributions}

V.M.R.W: Conception and Design, analysis and interpretation of data, drafting the article, final approval. 
D.Z.F: Conception and Design, analysis and interpretation of data, drafting the article, final approval.

B.S.P: Conception and Design, interpretation of data, drafting the article, final approval.

M.R: Interpretation of data, critically review, final approval.

L.A.V.: Interpretation of data, critically review, final approval.

S.M: Interpretation of data, drafting the article, final approval.

W.M.P: Interpretation of data, critically review, final approval.

E.R.V: Conception and Design, analysis and interpretation of data, drafting the article, final approval.

E.R.V.R: Interpretation of data, critically review, final approval.

M.R.Q: Conception and Design, analysis and interpretation of data, drafting the article, final approval.

\section{Acknowledgements}

Not Applicable.

\section{References}

1. Mergener CR, Kehrig RT, Traebert J. Sintomatologia músculo-esquelética relacionada ao trabalho e sua relação com qualidade de vida em bancários do Meio Oeste Catarinense. Saúde e Soc. 2008;17:171-81.

2. Hadgraft NT, Dunstan DW, Owen N. Models for understanding sedentary behaviour. In: Sedentary Behaviour Epidemiology. Springer; 2018. p. 381-403.

3. Moser AD, Kerhig R. 0 conceito de saúde e seus desdobramentos nas várias formas de atenção à saúde do trabalhador. Fisioter em Mov. 2017;19.

4. Mehralizadeh S, Dehdashti A, Motalebi Kashani M. Structural equation model of interactions between risk factors and work-related musculoskeletal complaints among Iranian hospital nurses. Work. 2017;57:137-46.

5. Da Costa BR, Vieira ER. Risk factors for work-related musculoskeletal disorders: A systematic review of recent longitudinal studies. Am J Ind Med. 2010;53:285-323.

6. Pinheiro FA, Tróccoli BT, Carvalho CV de. Validação do Questionário Nórdico de Sintomas Osteomusculares como medida de morbidade. Rev Saude Publica. 2002;36:307-12.

7. Lacerda EM, Nácul LC, da S Augusto LG, Olinto MTA, Rocha DC, Wanderley DC. Prevalence and associations of symptoms of upper extremities, repetitive strain injuries (RSI) and'RSI-like condition'. A cross sectional study of bank workers in Northeast Brazil. BMC Public Health. 2005;5:107. 
8. Lötters F, Burdorf A. Prognostic factors for duration of sickness absence due to musculoskeletal disorders. Clin J Pain. 2006;22:212-21.

9. Vuori IM. Dose-response of physical activity and low back pain, osteoarthritis, and osteoporosis. Med Sci Sports Exerc. 2001;33 6 Suppl:S551-86.

10. Sluka KA, O’Donnell JM, Danielson J, Rasmussen LA. Regular physical activity prevents development of chronic pain and activation of central neurons. J Appl Physiol. 2012;114:725-33.

11. Steihaug S, Ahlsen B, Malterud K. From exercise and education to movement and interaction. Treatment groups in primary care for women with chronic muscular pain. Scand J Prim Health Care. 2001;19:249-54. doi:10.1080/02813430152706783.

12. Heneweer H, Picavet HSJ, Staes F, Kiers H, Vanhees L. Physical fitness, rather than self-reported physical activities, is more strongly associated with low back pain: Evidence from a working population. Eur Spine J. 2012;21:1265-72.

13. Taanila HP, Suni JH, Pihlajamäki HK, Mattila VM, Ohrankämmen O, Vuorinen P, et al. Predictors of low back pain in physically active conscripts with special emphasis on muscular fitness. spine $\mathrm{J}$. 2012;12:737-48.

14. Jussila L, Paananen M, Näyhä S, Taimela S, Tammelin T, Auvinen J, et al. Psychosocial and lifestyle correlates of musculoskeletal pain patterns in adolescence: A 2-year follow-up study. Eur J Pain. 2014;18:139-46.

15. Mikkelsson LO, Nupponen H, Kaprio J, Kautiainen H, Mikkelsson M, Kujala UM. Adolescent flexibility, endurance strength, and physical activity as predictors of adult tension neck, low back pain, and knee injury: a 25 year follow up study. Br J Sports Med. 2006;40:107-13.

16. Weber VMR, Queiroga MR, Kiihn AL, Da-Silva LA, Ferreira SA, Portela BS. Strength indicators and usual physical activity among university administrative employees. Rev Bras Med do Trab. 2019;17:39-44.

17. Reis PF, Moro ARP, Contijo LA. A importância da manutenção de bons níveis de flexibilidade nos trabalhadores que executam suas atividades laborais sentados. Rev Produção Online. 2003;3. doi:10.14488/1676-1901.v3i3.563.

18. Bemben MG, Massey BH, Bemben DA, Misner JE, Boileau RA. Isometric muscle force production as a function of age in healthy 20- to 74-yr-old men. Med Sci Sports Exerc. 1991;23:1302-10.

19. Corlett EN, Bishop RP. A technique for assessing postural discomfort. Ergonomics. 1976;19:175-82. doi:10.1080/00140137608931530.

20. Fonseca M de JM da, Faerstein E, Chor D, Lopes CS. Validade de peso e estatura informados e índice de massa corporal: estudo pró-saúde. Rev Saude Publica. 2004;38:392-8.

21. Spencer EA, Appleby PN, Davey GK, Key TJ. Validity of self-reported height and weight in 4808 EPICOxford participants. Public Health Nutr. 2002;5:561-5.

22. Neto GAM, Polito MD, Lira VA. Fidedignidade entre peso e estatura reportados e medidos e a influência do histórico de atividade física em indivíduos que procuram a prática supervisionada de exercícios. Rev Bras Med Esporte. 2005;11:141-5. 
23. Guedes DP. Manual prático para avaliação em educação física. Editora Manole Ltda; 2006.

24. American College of Sports Medicine. ACSM's guidelines for exercise testing and prescription. Lippincott Williams \& Wilkins; 2013.

25. Mayorga-Vega D, Merino-Marban R, Viciana J. Criterion-related validity of sit-and-reach tests for estimating hamstring and lumbar extensibility: A meta-analysis. J Sports Sci Med. 2014;13:1-14.

26. Ferguson B. ACSM's Guidelines for Exercise Testing and Prescription 9th Ed. 2014. J Can Chiropr Assoc. 2014;58:328. https://www.ncbi.nlm.nih.gov/pmc/articles/PMC4139760/.

27. Janssen I, Heymsfield SB, Wang Z, Ross R. Skeletal muscle mass and distribution in 468 men and women aged 18-88 yr. J Appl Physiol. 2000;89:81-8.

28. Marcell TJ, Hawkins SA, Wiswell RA. Leg Strength Declines with Advancing Age Despite Habitual Endurance Exercise in Active Older Adults. J Strength Cond Res. 2013;:1.

29. Frontera WR, Hughes VA, Fielding RA, Fiatarone MA, Evans WJ, Roubenoff R. Aging of skeletal muscle: a 12-yr longitudinal study. J Appl Physiol. 2000;88:1321-6.

30. Delmonico MJ, Harris TB, Visser M, Park SW, Conroy MB, Velasquez-Mieyer P, et al. Longitudinal study of muscle strength, quality, and adipose tissue infiltration. Am J Clin Nutr. 2009;90:1579-85.

31. Goodpaster BH, Park SW, Harris TB, Kritchevsky SB, Nevitt M, Schwartz A V, et al. The loss of skeletal muscle strength, mass, and quality in older adults: the health, aging and body composition study. Journals Gerontol Ser A Biol Sci Med Sci. 2006;61:1059-64.

32. Bassey JE. Longitudinal changes in selected physical capabilities. Age Aging. 1998;27:12-6.

33. Bassey EJ, Harries UJ. Normal values for handgrip strength in 920 men and women aged over 65 years, and longitudinal changes over 4 years in 620 survivors. Clin Sci (Lond). 1993;84:331-7.

34. Reid N, Healy GN, Gianoudis J, Formica M, Gardiner PA, Eakin EE, et al. Association of sitting time and breaks in sitting with muscle mass, strength, function, and inflammation in community-dwelling older adults. Osteoporos Int. 2018;29:1341-50.

35. Weber VMR, Romanzini M, Queiroga MR, Panchoni C, Costa JC da, Silva LA da, et al. Associations between strength, flexibility, and painful symptomology in university staff. Work. In Press.

36. Jeon K, Kim T, Lee S-H. Effects of muscle extension strength exercise on trunk muscle strength and stability of patients with lumbar herniated nucleus pulposus. J Phys Ther Sci. 2016;28:1418-21.

37. Yaprak $Y$. The effects of back extension training on back muscle strength and spinal range of motion in young females. Biol Sport. 2013;30:201.

38. Berry DB, Padwal J, Johnson S, Englund EK, Ward SR, Shahidi B. The effect of high-intensity resistance exercise on lumbar musculature in patients with low back pain: a preliminary study. BMC Musculoskelet Disord. 2019;20:290.

39. Scarabottolo CC, Pinto RZ, Oliveira CB, Zanuto EF, Cardoso JR, Christofaro DGD. Back and neck pain prevalence and their association with physical inactivity domains in adolescents. Eur Spine $\mathrm{J}$. 2017;26:2274-80. 
40. Wahlström J, Lindegård A, Ahlborg Jr G, Ekman A, Hagberg M. Perceived muscular tension, emotional stress, psychological demands and physical load during VDU work. Int Arch Occup Environ Health. 2003;76:584-90.

41. Battié MC, Bigos SJ, Fisher LD, Spengler DM, Hansson TH, Nachemson AL, et al. The role of spinal flexibility in back pain complaints within industry. A prospective study. Spine (Phila Pa 1976). 1990;15:768-73.

42. Simoneau GG. The Impact of Various Anthropometric and Flexibility Measurements on the Sit-andReach Test. J Strength Cond Res. 1998;12:232-7.

\section{Figures}
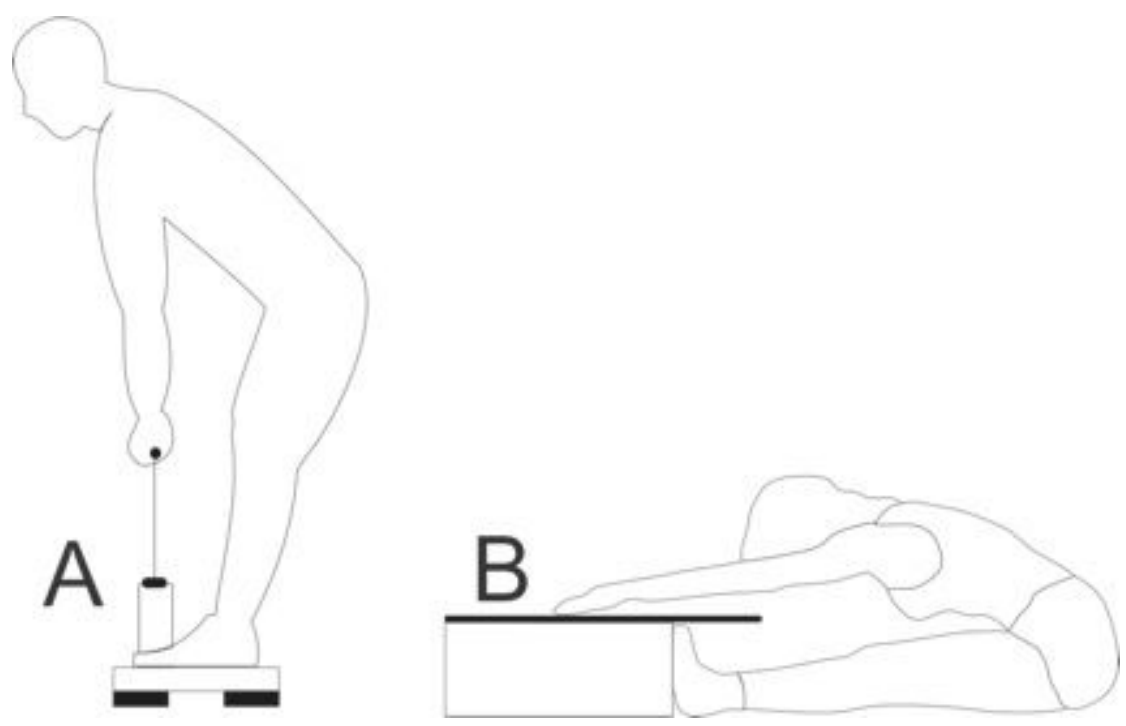

Figure 1

Strength test of lumbar traction and Sit-and-reach test 

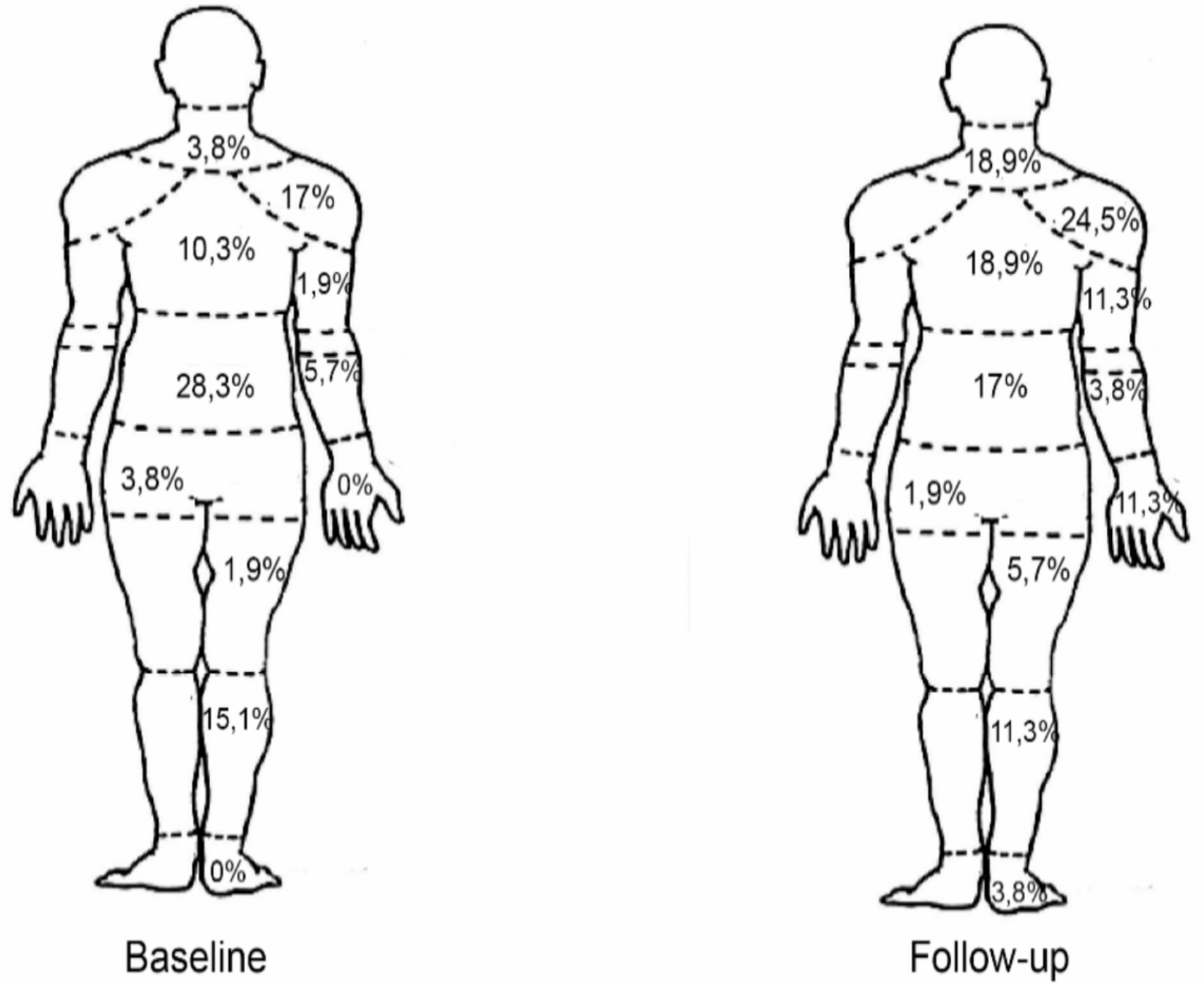

Figure 2

Spots and frequency of painful symptomatology 

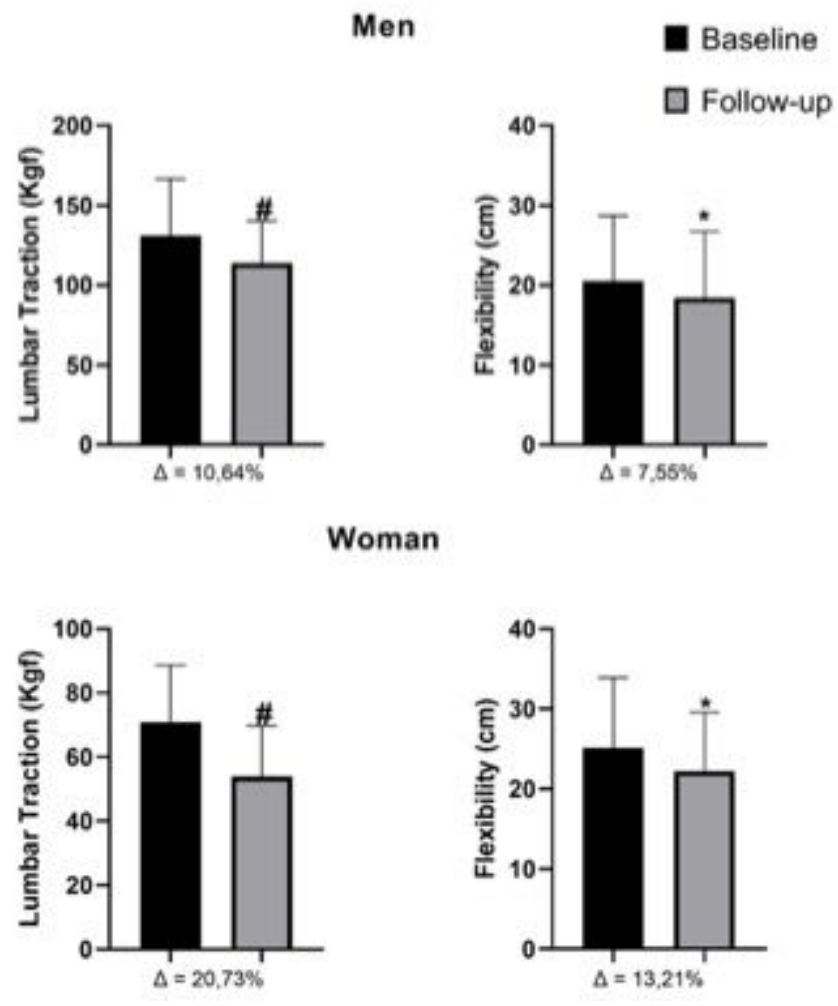

Figure 3

Comparison between the Baseline and follow-up Note: *:P<0,05; \#: P<0,001

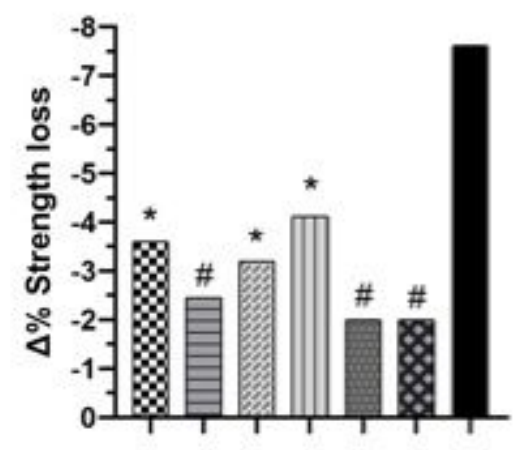

$\$$ Marcell et al., 2013

$\Xi$ Frontera et al., 2000

(203 Delmonico et al., 2009

띠 Goodpaster et al., 2006

… Bassey, 1998

\& Bassey \& Harries, 1993

- Present study

Figure 4

Comparisons with literature Note $\Delta \%=$ Strength variation; One sample T Test; ${ }^{*} \mathrm{P}<0,05 ; \# \mathrm{P}<0,001$ 